\section{6 OPEN ACCESS}

\title{
Economic determinants of diet in older adults: systematic review
}

\author{
Annalijn I Conklin,, ${ }^{1,2}$ Eva R Maguire, ${ }^{2}$ Pablo Monsivais ${ }^{2}$
}

\begin{abstract}
- Additional material is published online only. To view please visit the journal online (http://dx.doi.org/10.1136/jech2013-202513)

${ }^{1} \mathrm{MRC}$ Epidemiology Unit, Institute of Metabolic Science, University of Cambridge, Cambridge, UK

${ }^{2}$ UK Clinical Research

Collaboration Centre for Diet and Activity Research (CEDAR) University of Cambridge, Cambridge, UK
\end{abstract}

\section{Correspondence to} Dr Pablo Monsivais, CEDAR, Institute of Public Health, Box 296, Forvie Site, Robinson Way, Cambridge CB2 OSR, UK: pm491@medschl.cam.ac.uk

Received 15 February 2013

Revised 2 May 2013

Accepted 7 May 2013

Published Online First

12 June 2013

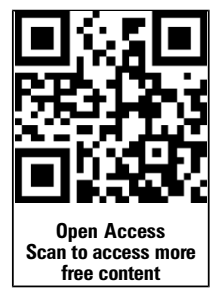

To cite: Conklin Al, Maguire ER, Monsivais $P$ J Epidemiol Community Health 2013;67:721-727.

\section{ABSTRACT}

Background and aims Many economic factors are associated with diet, yet the evidence is generally crosssectional. Older people are considered especially vulnerable to poor diets from negative changes to varied economic factors. This review extends current knowledge on known correlates to decipher actual economic determinants of diet in older adults.

Methods Eight bibliometric databases were searched between May and December 2012, supplemented by hand-searches, with no restrictions on publication date or country. Longitudinal studies, or reviews, were eligible when examining diet as a function of change in an economic factor in non-institutionalised adults $\geq 60$ years. Data were extracted using a standardised evidence table and quality assessed before narrative synthesis.

Results We found nine original studies for inclusion, of which eight examined change from work to retirement and one evaluated a food price intervention. Designs were generally pre-post without controls and varying in follow-up. Studies reported mixed impact on food spending and/or food intake. Retirement was shown to both reduce and have no impact on food spending and to have either positive and negative, or positive and no impact on food intake. Subgroup differences were observed, especially between men and women.

Conclusions Despite ample research on economic correlates of older adults' diets, little is still known about actual economic determinants of diet in this population. Studies of retirement suggest divergent effects in some but not all older people. Robust high-quality longitudinal studies to decipher economic drivers of diet must be prioritised in research and policy as firm conclusions remain elusive.

\section{INTRODUCTION}

Diet is integral to population-level health promotion and to chronic disease management. ${ }^{1}$ Yet, as adults enter older ages, they tend to eat nutritionally suboptimal diets, reduced variety, and fewer vegetables. $^{2-5}$ Overall older adults are not meeting recommendations for healthy diets, which are similar to those for younger adults. ${ }^{67}$ Eating well is therefore a necessary focus for public health and policy in tackling chronic disease and in supporting well-being through older age. ${ }^{8}{ }^{9}$ But, to support eating well, a clear understanding of how choice(s) can be changed and the context of dietary change is fundamental.

Promotion of healthy diets cannot be only through individual choices and supportive psychosocial factors; a supportive context is also key, particularly economic access. ${ }^{10-12}$ Various economic factors influence diet, including food prices and money available to purchase food. ${ }^{6}{ }^{12-17}$ Economic uncertainty might affect older people's food choice and diet variety as foods integral to a healthful diet (eg, fruit, vegetables, fish) can be perceived as a luxury; while healthier alternatives to common foods often carry a price premium. ${ }^{17}$ Modelling studies indicate that constraining food budgets can lower the nutritional adequacy of the diet. ${ }^{18}$ Estimates suggest that half of weekly income is needed for an older person on income support to eat a healthy $\operatorname{diet}^{19}$; while the considerably higher cost of therapeutic diets places an even greater burden on older people with limited incomes. ${ }^{19} 20$ Hence, having an adequate income is likely necessary to ensure a more varied and balanced diet for healthy older people, as suggested by Drewnowski et al. ${ }^{21}$

The economic sensitivity of diet is considered especially salient for older age individuals ${ }^{22}$ because they are more likely to have a low income, ${ }^{23}$ can experience two drops in income (through retirement and out-living savings), ${ }^{12}$ and have reduced opportunity to rebound from financial losses or shocks to their economic context as prospects for future employment are limited. ${ }^{24}$ For people aged 65 and over in the UK, food and nonalcoholic beverages comprise the greatest proportion of expenditures for basic necessities (eg, housing, fuel, power, and clothing and footwear) compared to younger age groups. ${ }^{25}$ The food share of the budget for basic necessities is even larger for older people on low income, ${ }^{26}$ and so it is perhaps not surprising that food is the necessity reduced first when income is restricted. ${ }^{11} 19202627$ Thus, changes in economic factors related to life transitions might constitute a key food choice determinant for this growing segment of the population.

Despite logical appeal, systematic examination of what happens to older people's diet over time when economic factors change is lacking. ${ }^{12} 28 \quad 29$ Nutrition and consumer research indicate that falling income led adults to reduce the variety and quantity of foods consumed, decreasing the intake of fish, rice, pasta, and frozen and salad vegetables. Conversely, rising income has been associated with the adoption of a more healthful, varied diet. Notably, the individuals experiencing a decrease in income imposed more dietary changes than those experiencing an increase. ${ }^{29} 30$ Economic models suggest food consumption shifts with a change in relative price, ${ }^{31} 32$ with different scenarios of taxation and/or subsidy, ${ }^{33}$ and that some social groups are more price responsive in demand for foods/components that are taxed and/or subsidised. ${ }^{34}$ But, dietary effects from change(s) in economic factors may not be sustained over time, ${ }^{32}$ and immediate 
effects may counter the expected beneficial direction for social groups most in need of support for healthy eating. ${ }^{33} 35$

This study aimed to systematically review prospective studies, or potential reviews, with data on diet of older adults as a function of change in economic variable(s). This paper extends current knowledge on correlates to decipher actual economic determinants of diet in older adults, to better understand a recurring concern about the potential vulnerability of older people to constraints on their choices in healthful eating.

\section{METHODS}

\section{Search and selection}

Peer-reviewed literature was systematically searched using eight bibliometric databases (PubMed/Medline, SCOPUS, EconLit, PsychInfo, ASSIA, Web of Science, Embase and British Nursing Index); hand-searches (Food Choice Conference abstracts and references in retrieved full-texts); and expert advice. We followed a common approach for systematic reviews as given by the Cochrane collaboration. ${ }^{36}$ Since the Cochrane method for quality assessment (designed for appraising clinical practice) considers observational study evidence as low quality, we employed the Effective Public Health Practice Project tool and the Newcastle-Ottawa scale-both identified by the UK's HTA Programme as 'best' tools for evaluating observational studies. ${ }^{37}$ We applied free-text and thesaurus terms for 'eating behaviour', 'economic environment', 'change' and 'older people' after consulting a medical research librarian (see web only appendix A). No limitations were imposed on publication date, country or language, except in SCOPUS (English and French). Subject area was only restricted in SCOPUS and PsychInfo as half of records had unrelated subjects. Searches were performed separately by AC and EM between May and December 2012.

\section{Inclusion and exclusion criteria}

Our review included eligible longitudinal studies, or reviews, examining diet in community-dwelling older individuals as a function of change in an economic factor (eg, income, price, employment). Studies were considered when participants, or subgroup analyses, involved adults aged 60 and over. Criteria for exclusion included: cross-sectional design; exposure of interest lacking; position papers; editorials; institutionalised elderly; non-diet outcomes; unspecified age group; weight management interventions; and measurement validation studies. Intervention studies were excluded unless measuring diet as a function of financial incentives or change in another economic factor(s) (eg, reduced food price, subsidies, or coupons).

\section{Screening}

Two reviewers (AC and EM) screened titles and abstracts for potential eligibility and removed records based on exclusion criteria. Abstracts were examined further for full-text retrieval, excluding additional records. Retrieved papers were read in full and references followed up.

\section{Quality assessment, data extraction and analysis}

$\mathrm{AC}$ and EM independently assessed quality using an adapted checklist of itemised criteria, consisting of 25 questions and three response categories ('yes', 'no' and 'can't tell'). Criteria covered: research question, design, representativeness, sampling, protection against bias and confounding (ie, comparability), completeness, results, conclusions and generalisability. A study was assessed as of high quality when approximately $80 \%$ of responses to checklist questions were 'yes', and of low quality when approximately 20\% were 'yes'. Completed assessments were cross-checked between reviewers, with one study additionally appraised by the senior investigator (PM).

Studies were analysed using a standardised evidence table with a priori determined headings. AC and EM extracted data on: stated study objective, design, year, population, geographical setting, exposure description, outcome(s) measured, reported findings, author and source. Reported findings were synthesised through a narrative approach while quality assessment helped interpret and explain differences in reported results. Any disagreements on eligibility, quality or synthesis were discussed with the senior investigator (PM) and resolved by consensus.

\section{RESULTS}

We identified 118 original studies and no reviews eligible for inclusion, of which nine met criteria for data extraction and quality review (figure 1). ${ }^{38-46}$ These mainly reported on work undertaken between the early 1990s and mid-2000s in a European context $\left(\mathrm{UK},{ }^{38}{ }^{43}\right.$ France, ${ }^{40}$ Finland, ${ }^{46}$ Sweden, ${ }^{39}$ and the Netherlands ${ }^{42}$ ), with some work conducted in the USA. ${ }^{4144} 45$

\section{Study quality}

Despite relatively scarce evidence, study quality was generally good. Eight included studies were rated as of high ${ }^{424} 46$ or medium $^{38} 39414345$ quality; only one ${ }^{40}$ was considered low quality (see web only appendix B). We found only three studies which satisfied most quality criteria on design and comparability and were therefore rated as high quality. ${ }^{42} 4446$ Compared to these high quality studies, medium studies had less study completeness and poorer reporting of results.

\section{Study design and sample characteristics}

Studies used before-and-after designs with prospective cohort or panel survey data (table 1). Length of observation varied, ranging from 3-5 months up to 11 years; the oldest studies identified did not report on the period of study. ${ }^{38-40}$ Sample sizes also varied widely, from under 50 to over 6000. Most examined impact in both men and women, ${ }^{38} 40 \quad 4144-46$ and one explicitly analysed gender differences. ${ }^{44}$ Two focused on men only ${ }^{42}$ and one on women. ${ }^{39}$ Participants tended to be a mix of occupational or educational levels but some studies involved specific occupations, mostly office-based. ${ }^{38-40} 46$

\section{Exposure definition}

Most studies defined the change in respondents' economic context in terms of retirement from work, ${ }^{38-44} 46$ except for one intervention study which examined change in food price. ${ }^{45}$ Generally, retirement was operationalised as a specific (legal) age or individual self-report. Some studies did not report an operational definition. 394042

\section{Outcomes examined}

Food spending and/or food intake were the dietary outcomes examined (table 2). Diverse measures were used to assess food intake. Four studies measured total diet based on healthful eating habits or types of foods eaten, ${ }^{39} 404246$ two others assessed dietary components (eg, fibre ${ }^{38}$ or fruits and vegetables ${ }^{45}$ ). Assessment methods also varied, including: diet interview, ${ }^{39}$ food frequency questionnaire ${ }^{42} 4546$ and food record/ diary. ${ }^{38} 40$ Multiple approaches were employed to examine overall household food spending (weekly, annual) ${ }^{41} 43-45$ or individual spending on eating out, ${ }^{44}$ often using panel survey data. Additional outcomes measured included anthropometric measures, ${ }^{39} 4244$ physical activity ${ }^{40} 42$ and wellbeing. ${ }^{40}$ 


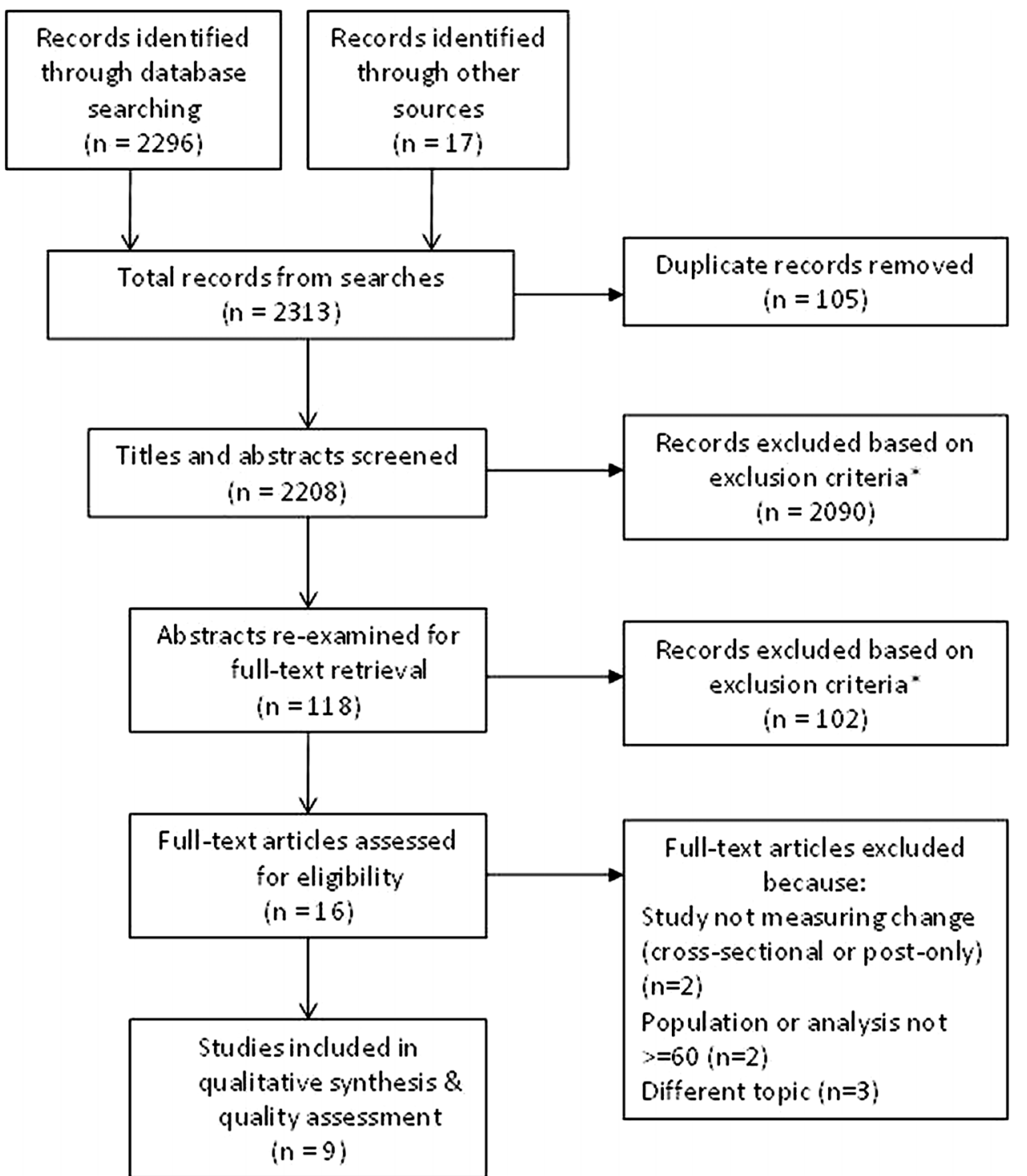

Figure 1 Modified PRISMA flow diagram of literature search and study selection. *Exclusion criteria: cross-sectional design; exposure of interest lacking; position papers; editorials; institutionalised elderly; non-diet outcomes; unspecified age group; weight management interventions; and measurement validation studies.

\section{Main findings}

Studies documented a pattern of mixed impact on food spending and consumption as a function of change in the economic context (table 2). Studies examining a shift from employment to retirement found spending decreased (7\% to 11\%) for certain groups (eg, co-habiting, involuntary retired) or settings (eg, eating out), but spending also stayed constant for single-person households, the voluntarily retired and home consumption. $^{41} 43 \quad 44$ Reported effects came from three good quality studies of sufficient follow-up to permit accurate assessment of lasting effects on spending. The intervention study, in which fruit and vegetable prices were reduced by nearly $50 \%$, reported decreased spending of low-income seniors at their most recent supermarket visit, with the greatest impact among seniors using the programme weekly. However, the study could not account for substitution in produce spending between supermarket and intervention site. ${ }^{45}$

Six studies examined dietary outcomes and all reported an increase in at least some aspect of food intake as a function of employment transition to retirement (table 2). Two studies revealed slight increases in daily fibre intake in British men and women, particularly when breakfast was consumed, ${ }^{38}$ or in consumption of pastry, potato chips and related food items by Swedish women. ${ }^{39}$ The food price intervention study found more low-income seniors in New York consumed vegetables and fruits 3 months after retirement. ${ }^{45}$ Finally, two studies documented an increased prevalence of healthy food habits in Finnish women who were retired compared to the employed, ${ }^{46}$ and an increased weekly intake of fish and vegetables and daily glasses of juice and alcohol in Dutch men. ${ }^{42}$

Some studies showed no impact on food consumption. For example, the main British foods contributing to increased fibre intake and the proportion of older people below recommendations stayed constant. ${ }^{38}$ Post-retirement improvements in women's healthy food habits were not seen in retired Finnish men compared to employed men. ${ }^{46}$ A small French study also found the distribution of nutrients appeared unchanged after retirement. ${ }^{40}$ Although this study was assessed as being of low quality, findings corroborate similar results of no impact from other good quality studies. 
Table 1 Characteristics of included studies

\begin{tabular}{|c|c|c|c|c|c|c|c|c|}
\hline Stated study objective & Study design & Year & Setting & $\begin{array}{l}\text { Study population } \\
\text { (n) }\end{array}$ & Description of exposure & Outcome(s) measured & Author & Source \\
\hline $\begin{array}{l}\text { To fill gap in longitudinal evidence on food habits } \\
\text { before and after old age retirement }\end{array}$ & $\begin{array}{l}\text { Pre-post, with control } \\
\text { (survey, mean } 3 \text { years; } \\
\text { adjusted for } 7 \text { covariates) }\end{array}$ & $\begin{array}{l}2000-2002 \\
\text { and } 2007\end{array}$ & $\begin{array}{l}\text { Helsinki, } \\
\text { Finland }\end{array}$ & $\begin{array}{l}\text { Municipal } \\
\text { employees, males } \\
\text { ( } n=527) ; \text { females } \\
(n=1824)\end{array}$ & $\begin{array}{l}\text { Old age retirement (63- } \\
68 \text { years in Finland) }\end{array}$ & $\begin{array}{l}\text { Healthy food habits (FFQ, } \\
\text { 8-item index) }(6 / 8=\text { healthy) }\end{array}$ & $\begin{array}{l}\text { Helldán } \\
\text { et al }{ }^{46}\end{array}$ & $\begin{array}{l}\text { PubMed/ } \\
\text { Medline }\end{array}$ \\
\hline $\begin{array}{l}\text { (1) To understand how retirement decisions of older } \\
\text { Americans influence household food consumption } \\
\text { patterns by gender; (2) to examine impact of the } \\
\text { change in food consumption on weight }\end{array}$ & $\begin{array}{l}\text { Panel survey (Health and } \\
\text { Retirement Study) }\end{array}$ & 1992-2002 & USA & $\begin{array}{l}\text { Population aged } 50 \\
+(n=6012)\end{array}$ & $\begin{array}{l}\text { Retirement of self and spouse } \\
\text { (ie, not working for pay } \\
\text { currently and for past } \\
3 \text { months, and self-reported } \\
\text { retired) }\end{array}$ & $\begin{array}{l}\text { Household spending on food } \\
\text { at home; individual spending } \\
\text { on eating out; BMI }\end{array}$ & $\begin{array}{l}\text { Chung } \\
\text { et }\left.a\right|^{44}\end{array}$ & Hand-searched \\
\hline $\begin{array}{l}\text { To study the impact of retirement on diet, physical } \\
\text { activity, BMI and waist circumference, over a 5-year } \\
\text { follow-up }\end{array}$ & $\begin{array}{l}\text { Prospective cohort, with } \\
\text { control (retired vs. } \\
\text { employed, by job activity) }\end{array}$ & 1997-2002 & $\begin{array}{l}\text { Rural town, } \\
\text { Netherlands }\end{array}$ & $\begin{array}{l}\text { Men aged } 50-65 \\
(n=288)\end{array}$ & $\begin{array}{l}\text { Not specifically defined } \\
\text { (retirement) }\end{array}$ & $\begin{array}{l}\text { Food intake (FFQ); physical } \\
\text { activity; anthropometric } \\
\text { measures }\end{array}$ & $\begin{array}{l}\text { Nooyens } \\
\text { et } a{ }^{42}\end{array}$ & $\begin{array}{l}\text { Web of } \\
\text { Science }\end{array}$ \\
\hline $\begin{array}{l}\text { To preliminarily evaluate the impact of the Veggie } \\
\text { Mobile [intervention] on the shopping and eating } \\
\text { habits of a group of community-dwelling seniors }\end{array}$ & $\begin{array}{l}\text { Pre-post, no control } \\
\text { (postal survey) }\end{array}$ & 2008 & $\begin{array}{l}\text { New York, } \\
\text { USA }\end{array}$ & $\begin{array}{l}\text { Residents aged } 55+ \\
(n=43)\end{array}$ & $\begin{array}{l}\text { Reduced cost of fruit and } \\
\text { vegetable provided weekly } \\
\text { through a mobile van }\end{array}$ & $\begin{array}{l}\text { F\&V intake }(6 \text {-item } \\
\text { questionnaire, } 24 \mathrm{~h}) \text {; } \\
\text { frequency of supermarket } \\
\text { visits and amount spent }\end{array}$ & $\begin{array}{l}\text { Abusabha } \\
\text { et } a 1^{45}\end{array}$ & $\begin{array}{l}\text { Web of } \\
\text { Science }\end{array}$ \\
\hline $\begin{array}{l}\text { To revisit spending on food at retirement and } \\
\text { explore the hypothesis that retirement is } \\
\text { accompanied by a negative wealth shock that } \\
\text { causes people to reduce spending }\end{array}$ & $\begin{array}{l}\text { Panel survey (British } \\
\text { Household Panel Survey) } \\
\text { (involuntary/early vs } \\
\text { voluntary retired) }\end{array}$ & 1991-2002 & UK & $\begin{array}{l}\text { Men aged } 45-64 \\
(n=2000)\end{array}$ & $\begin{array}{l}\text { Retirement (ie, first year man is } \\
\text { both not working and } \\
\text { self-reports retired) }\end{array}$ & Weekly food spending & Smith $^{43}$ & Hand-searched \\
\hline $\begin{array}{l}\text { (1) To examine the relationship between } \\
\text { consumption behaviour and retirement; ( } 2 \text { ) to test } \\
\text { the bargaining model by comparing married couples } \\
\text { behaviour at retirement to that of singles }\end{array}$ & $\begin{array}{l}\text { Panel survey (Panel Study } \\
\text { of Income Dynamics) } \\
\text { (unmarried vs matched } \\
\text { co-habiting pairs) }\end{array}$ & $\begin{array}{l}1979-1986 \\
\text { and 1989- } \\
2002\end{array}$ & USA & $\begin{array}{l}\text { Population aged } \\
45-74(n=553)\end{array}$ & $\begin{array}{l}\text { Retirement of husband (ie, } \\
\text { latest reported year retired) }\end{array}$ & $\begin{array}{l}\text { Annual household food } \\
\text { spending (1985 US\$) }\end{array}$ & $\begin{array}{l}\text { Lundberg } \\
\text { et }\left.a\right|^{41}\end{array}$ & Hand-searched \\
\hline $\begin{array}{l}\text { To evaluate dietary habits and body composition in } \\
\text { a longitudinal study of municipally employed } \\
\text { women before and after retirement }\end{array}$ & $\begin{array}{l}\text { Pre-post, no control } \\
\text { (median 5-month interval) }\end{array}$ & $\begin{array}{l}\text { Not } \\
\text { reported }\end{array}$ & $\begin{array}{l}\text { Malmo, } \\
\text { Sweden }\end{array}$ & $\begin{array}{l}\text { Female municipal } \\
\text { employees }(n=116)\end{array}$ & $\begin{array}{l}\text { Not specifically defined (legal } \\
\text { old age retirement) }\end{array}$ & $\begin{array}{l}\text { Food intake (diet interview); } \\
\text { height; weight; skinfolds; and } \\
\text { waist }\end{array}$ & $\begin{array}{l}\text { Steen } \\
\text { et } a \beta^{39}\end{array}$ & $\begin{array}{l}\text { PubMed/ } \\
\text { Medline }\end{array}$ \\
\hline $\begin{array}{l}\text { To examine shifts in fibre intakes between pre- and } \\
\text { post-retirement periods }\end{array}$ & $\begin{array}{l}\text { Pre-post, no control } \\
\text { (survey) }\end{array}$ & $\begin{array}{l}\text { Not } \\
\text { reported }\end{array}$ & London, UK & $\begin{array}{l}\text { Near-retired } \\
\text { employees of } 2 \\
\text { firms }(n=183)\end{array}$ & $\begin{array}{l}\text { Retirement from work (ie, } \\
\text { minimum } 6 \text { months not in } \\
\text { work) }\end{array}$ & $\begin{array}{l}\text { Fibre intake (7-day weighed } \\
\text { diary) }\end{array}$ & $\begin{array}{l}\text { Davies } \\
\text { et }\left.a\right|^{38}\end{array}$ & $\begin{array}{l}\text { PubMed/ } \\
\text { Medline }\end{array}$ \\
\hline $\begin{array}{l}\text { To investigate the impact of retirement on one's } \\
\text { eating habits and food intake }\end{array}$ & $\begin{array}{l}\text { Pre-post, no control } \\
\text { (comparison } 6 \text { months pre } \\
\text { with } 19 \text { months post) }\end{array}$ & $\begin{array}{l}\text { Not } \\
\text { reported }\end{array}$ & $\begin{array}{l}\text { Toulouse, } \\
\text { France }\end{array}$ & $\begin{array}{l}\text { Persons near } \\
\text { retirement }(n=52), \\
\text { majority teachers }\end{array}$ & $\begin{array}{l}\text { Not specifically defined } \\
\text { (retirement) }\end{array}$ & $\begin{array}{l}\text { Food intake (3-day diary); } \\
\text { physical activity, perceived } \\
\text { wellbeing }\end{array}$ & $\begin{array}{l}\text { Lauque } \\
\text { et } a^{40}\end{array}$ & $\begin{array}{l}\text { PubMed/ } \\
\text { Medline }\end{array}$ \\
\hline
\end{tabular}


Table 2 Summary of reported findings from included studies

\begin{tabular}{|c|c|c|c|c|}
\hline $\begin{array}{l}\text { Study } \\
\text { quality }\end{array}$ & Author & $\begin{array}{l}\text { Food } \\
\text { spending }\end{array}$ & $\begin{array}{l}\text { Food } \\
\text { intake }\end{array}$ & Details \\
\hline High & $\begin{array}{l}\text { Helldán } \\
\text { et al }{ }^{46}\end{array}$ & & $\uparrow, \cong$ & $\begin{array}{l}\text { Prevalence of healthy food habits in retired women increased (41-53\%), compared to still employed women } \\
(39-45 \%) \text {. No change seen in men after retirement }(23-29 \%) \text { vs remaining employed (24-27\%). } \\
\text { Sociodemographic and health-related factors did not explain difference among women. Retirement accentuated } \\
\text { existing sex differences in healthy food habits. }\end{array}$ \\
\hline High & Chung et al ${ }^{44}$ & $\downarrow, \cong$ & & $\begin{array}{l}\text { Spending on eating out reduced by a mean of } \$ 10 \text { per month when after the individual retired and by } \$ 7 \text { after } \\
\text { the spouse retired. The wife's, but not husband's, retirement decreased the spouse's monthly spending on } \\
\text { eating out by } \$ 13 \text {. Retirement did not affect household spending on food at home. Weight gain was weakly } \\
\text { predicted by spending on eating out. }\end{array}$ \\
\hline High & $\begin{array}{l}\text { Nooyens } \\
\text { et } a l^{42}\end{array}$ & & $\uparrow, \downarrow$ & $\begin{array}{l}\text { Men retired from former active jobs consumed less potatoes, more fish, and more juice each week, than older } \\
\text { men still working. Men retired from sedentary jobs consumed more alcoholic beverages, more vegetables, less } \\
\text { meat, less potatoes and less milk on a weekly basis. }\end{array}$ \\
\hline Medium & $\begin{array}{l}\text { Abusabha } \\
\text { et } a /^{45}\end{array}$ & $\downarrow$ & $\uparrow$ & $\begin{array}{l}48 \% \text { reduced cost of } F \& V \text { increased vegetable consumption from } 33 \% \text { to } 51 \% \text {; and increased fruit intake from } \\
53 \% \text { to } 63 \% \text {. Average spending at last supermarket trip decreased by nearly } \$ 15 \text { and weekly Veggie Mobile } \\
\text { shoppers spent } \$ 29 \text { less at last supermarket visit than seniors using the programme less often. }\end{array}$ \\
\hline Medium & Smith $^{43}$ & $\downarrow_{1} \cong$ & & $\begin{array}{l}\text { Involuntary retirement reduced food spending by } 7-11 \% \text { (depending on definition used). Effect greater for } \\
\text { involuntarily early retired who have no employer pension and with no educational qualifications. }\end{array}$ \\
\hline Medium & $\begin{array}{l}\text { Lundberg } \\
\text { et } a /^{41}\end{array}$ & $\downarrow_{1} \cong$ & & $\begin{array}{l}\text { Co-habiting households decrease their food expenditures, consumed both at and away from home, by about } \\
9 \% \text { after retirement of male. Retirement in single-person household did not show any significant decrease in } \\
\text { food consumption. }\end{array}$ \\
\hline Medium & Steen et $a l^{\beta 9}$ & & $\uparrow, \downarrow$ & $\begin{array}{l}\text { Clear decreasing tendency of intake of energy (by } 7 \% \text { ), protein (by } 8 \% \text { ), fat (by } 10 \% \text { ), calcium (by } 12 \% \text { ) and } \\
\text { riboflavin (by } 11 \% \text { ) from before to after retirement. High-energy food items such as pastry and potato chips } \\
\text { increased after retirement. Small changes in other items (not specified) seen after retirement. Average number } \\
\text { daily meals decreased after retirement (from } 5.2 \text { to } 4.8 \text { ). }\end{array}$ \\
\hline Medium & Davies et al ${ }^{38}$ & & $\uparrow, \cong$ & $\begin{array}{l}\text { Mean daily fibre intake increased slightly after retirement (from } 17.6 \pm 6.5 \text { to } 18.4 \pm 6.1 \mathrm{~g} / \text { day), especially when } \\
\text { breakfast was consumed. Percentage of participants below recommended levels of fibre did not change. Also, } \\
\text { the main food groups contributing to dietary fibre intake (eg, vegetables, breads, breakfast cereals and fruits) } \\
\text { remained unchanged. }\end{array}$ \\
\hline Low & $\begin{array}{l}\text { Lauque et al } \\
40\end{array}$ & & $\uparrow, \cong$ & $\begin{array}{l}\text { Retirement increased the percentage of participants spending over } 30 \mathrm{~min} \text { to eat lunch (from } 25.5 \% \text { to } 45.5 \% \text { ), } \\
\text { and the frequency of eating out and having guests for meals. Men ate more plant protein after retirement. The } \\
\text { distribution of nutrients did not change after retirement, staying near recommended daily allowance except low } \\
\text { calcium intake which increased slightly (from } 750.5 \pm 270 \text { to } 781 \pm 308 \mathrm{mg} / \text { day in women; and from } 702 \pm 186 \text { to } \\
837.6 \pm 239.5 \mathrm{mg} / \text { day in men). }\end{array}$ \\
\hline
\end{tabular}

$\uparrow$, increase; $\downarrow$, decrease; $\cong$, no change.

Finally, two studies reported decreases in food intake. A study of female Swedish municipal employees showed a decreasing tendency in average number of daily meals and in nearly all nutrients. ${ }^{39}$ Another study of rural Dutch men also documented reductions in consumption of meat and potatoes and milk, depending on level of occupational activity. ${ }^{42}$

\section{DISCUSSION}

This review has shown how, despite ample research on economic correlates of diet in older people, robust evidence of actual economic determinants remains scarce and largely framed in terms of employment transition to retirement. No relevant reviews were identified by our searches. However, we found nine relatively good quality studies reporting a mixed impact on food spending and/or food intake. Expenditures decreased and also remained unchanged; food intake increased and also decreased or stayed constant. Studies showed gender differences in impact on food spending and dietary intake. Effects also varied by retirement voluntariness, occupational activity level, living arrangements or purchase locations.

Reported results suggest that when an individual and/or their spouse retires, they reduce spending on food eaten away from, but not at, home. Notably, gender differences were observed insofar as spouses reduced away-from-home food spending when the wife, but not the husband, retired. Retirement's impact on food spending differed by living arrangements, with reductions occurring in co-habiting, but not single-person, households. The nature of retirement was also important, as larger decreases in food spending were reported for men retiring involuntarily despite their smaller income drop compared to men voluntarily retiring. The documented expenditure decreases were notably similar to the amount indicated by UK pensioners as sufficient to enable them to improve their diet. ${ }^{47}$ However, whose diet is impacted and by how much will be a matter not only of employment-related economic change but also of psychosocial context, which does not appear to be explained by known sociodemographic or health-related factors.

The impact on food intake depended on the dietary aspect measured and in whom, although increases were documented in all six studies reporting this outcome. For example, prevalence of healthful consumption patterns increased after retirement among Finnish women and Dutch men. However, employment-related economic change could also negatively impact women's diets through, for example, limiting the number of daily meals-a finding also reported in a recent qualitative study. ${ }^{48}$ Given the heterogeneity of food intake measures, reported increases and decreases are difficult to interpret in terms of contributing to dietary healthfulness. Whereas decreases in overall quantity might promote health if optimal nutrition remains high or improves, increased consumption of high-energy food items after retirement is likely to undermine nutritionally optimal diets.

The observed pattern of mixed impact on older people's diet in reported results could be explained by the complex context of employment-related economic change. The transition from employment to retirement involves diverse interconnected factors that are not only economic. For women at least, Brown 
et $a l^{48}$ illustrated well the complex link of life changes shaping dietary decisions and behaviours although financial changes and constraints most commonly and profoundly impacted their food choice. Another explanation for heterogeneity of documented impact is study differences in follow-up and therefore persistence of effect. Some results more likely reflected short-term impact on food spending or consumption (5-6 months after retirement), while follow-up over several years was perhaps more indicative of long-term behavioural changes. Yet, the average time spent in retirement prior to follow-up was only specified in two out of nine studies reviewed. Finally, betweencountry variation in policies for welfare, healthcare or mandatory retirement could also explain findings of mixed impact. Future studies should be designed to collect and analyse multilevel data on other socioeconomic characteristics, including length of and reasons for retirement, to clarify the role and relative contribution of multiple intersecting factors as potential economic determinants of older people's diet.

This review may have missed other evidence on economic mechanisms determining diet from grey literature as it focused exclusively on longitudinal studies in peer-reviewed publications. Included studies were also restricted to adults aged 60 years and older, which may have biased economic exposures analysed to employment-related change. This review is nevertheless the most comprehensive reported to date, with searches conducted by two reviewers in eight databases covering interdisciplinary literature from a wide range of social sciences, not only the health field. We did not restrict publication date to allow for potentially older studies, and used broad terms to help ensure the widest possible evidence was captured.

Our finding of scarce robust studies of economic determinants of older people's dietary habits is not new, ${ }^{12}{ }^{28}$ but one might expect the growth in empirical work on economic influences to advance the evidence base. There still exists a large knowledge gap concerning economic determinants of diet in older ages, other than retirement. Among longitudinal studies of retirement and diet, the use of comparison groups remains underdeveloped and the exposure tends to have unknown duration. What has emerged from existing evidence is a confirmation of the acknowledged complexity of studying determinants of diet in older ages. We therefore reaffirm the call to public health researchers to analyse and theoretically account for combined effects and interactions between change in a given economic factor, such as employment, and other dimensions of life transition in older individuals. ${ }^{49-51}$

\section{CONCLUSION}

Despite the well established view that older people's diets are especially vulnerable to varied economic influences, robust evidence of economic determinants remains scarce. Only a small body of work has developed on the transition from employment to retirement as a dynamic period of economic change. It was clear that the direction and size of impact on food spending or habits differed across subgroups analysed, but much less is known about persistence of reported effects. Thus, firm conclusions about economic determinants of diet in older people are difficult to draw.

If public health and policy aim to promote healthy eating and support behaviour change, then greater attention is needed to reproduce and add to this burgeoning evidence base using controlled longitudinal studies, with different exposures of defined periods and multiple dietary follow-up in various subgroups of the older population. Only then can we know whether recurring concerns about increasing inflation and rising food prices have an impact, if any, on eating behaviours, how lasting they are and for which groups of older people.

\section{What is already known on this subject}

- Many economic factors such as low-income and food price are known to be associated with eating behaviours.

- Older people are considered especially vulnerable to poor diets from negative changes in the economic context.

- Although some studies suggest that a decrease in, for example, income might restrict food choice, no study has assessed comprehensively the evidence base in older people.

\section{What this study adds}

- This review revealed that the change in one economic factor, namely employment to retirement, has divergent effects in some but not all older people and that little is still known about most economic correlates of diet.

- It confirms the need to advance public health research in deciphering economic determinants of diet by analysing and accounting for synergies and interactions of complex socioeconomic exposures.

Acknowledgements We gratefully acknowledge Dr Vivien Hendry and Theodore Cosco for their very helpful and insightful comments on earlier drafts and we also thank the anonymous reviewers for their contribution to further improvements of this paper.

Contributors $A C$ conceived and designed the study and led drafting of the paper. AC and EM collected, analysed and interpreted data. PM informed study design and execution, as well as interpreted data. All authors revised the drafted paper critically for important intellectual content and all authors gave final approval of the version to be published.

Funding $\mathrm{AC}$ acknowledges full PhD funding from the Gates Cambridge Trust. PM and EM are supported by the Centre for Diet and Activity Research (CEDAR), a UK Clinical Research Collaboration (UKCRC) Public Health Research Centre of Excellence. Funding from the British Heart Foundation, Economic and Social Research Council, Medical Research Council, National Institute for Health Research and Wellcome Trust, under the auspices of the UK Clinical Research Collaboration, is gratefully acknowledged.

\section{Competing interests None declared.}

Provenance and peer review Not commissioned; externally peer reviewed.

Open Access This is an Open Access article distributed in accordance with the Creative Commons Attribution Non Commercial (CC BY-NC 3.0) license, which permits others to distribute, remix, adapt, build upon this work non-commercially, and license their derivative works on different terms, provided the original work is properly cited and the use is non-commercial. See: http://creativecommons.org/ licenses/by-nc/3.0/

\section{REFERENCES}

1 Mozaffarian D, Appel LJ, Van Horn L. Components of a cardioprotective diet: new insights. Circulation 2011;123:2870-91.

2 Shepherd A. Nutrition through the life span. Part 3: adults aged 65 years and over. Brit J Nurs 2009;18:301-7.

3 Scientific Advisory Committee on Nutrition (SACN). The nutritional wellbeing of the British population. London: SACN, 2008.

4 Millen BE, Silliman RA, Cantey-Kiser J, et al. Nutritional risk in an urban homebound older population: the nutrition and healthy aging project. I Nutr Health Aging 2001;5:269-77.

5 Szczeciñska A, Kozlowska K, Roszkowski W, et al. Differences in frequency of fruit and vegetables intake among older Europeans: food in Later Life Project. Pol J Nat Sci 2007:(Suppl 4):244-51. 
6 McGandy RB, Russell RM, Hartz SC, et al. Nutritional status survey of healthy noninstitutionalized elderly: energy and nutrient intakes from three-day diet records and nutrient supplements. Nutr Res 1986;6:785-98.

7 World Health Organization. Keep fit for life: meeting the nutritional needs of older persons. Geneva: World Health Organization, 2002.

8 Commission of European Communities. Together for Health: a strategic approach for the EU 2008-2013. White Paper, COM(2007) 630 final. Brussels: European Commission, 2007

9 Department of Health. A new ambition for old age: next steps in implementing the National Service Framework for Older People. London: Department of Health, 2006.

10 Yudkin J. Man's choice of food. Lancet 1956;i:645-9.

11 McKenzie JC. Economic influences on food choice. Nutr Food Sci 1979:79:4-7.

12 Cohen C. Social and economic factors in the nutrition of the elderly. Proc Nutr SoC 1974:33:51-7

13 Lo Y-T, Chang Y-H, Lee M-S, et al. Health and nutrition economics: diet costs are associated with diet quality. Asia Pac J Clin Nutr 2009;18:598-604.

14 Herne $S$. Research on food choice and nutritional status in elderly people: a review. Br Food J 1995:97:12-29.

15 Dean M, Raats M, Grunert KG, et al. The Food in Later Life Team. Factors influencing eating a varied diet in old age. Public Health Nutr 2009;12:2421-7.

16 Lallukka T, Laaksonen M, Rahkonen 0, et al. Multiple socio-economic circumstances and healthy food habits. Eur J Clin Nutr 2006;61:701-10.

17 Denny $\mathrm{A}$. An overview of the role of diet during the ageing process. $\mathrm{Br}$ Community Nurs 2008;13:58-67.

18 Darmon N, Ferguson EL, Briend A. A cost constraint alone has adverse effects on food selection and nutrient density: an analysis of human diets by linea programming. J Nutr 2002;132:3764-71.

19 Leather S. Less money, less choice: poverty and diet in the UK today. In: Council NC, ed. Your food-whose choice? London: Stationery Office (HMSO) 1992:72-94

20 Hanes FA, De Looy AE. Can I afford the diet? Hum Nutr App/ Nutr 1987;41:1-12.

21 Drewnowski $A$, Renderson SA, Driscoll $A$, et al. The dietary variety score: assessing diet quality in healthy young and older adults. J Am Diet Assoc 1997:97:266-71.

22 Hall MRP. A good mixed diet. Age Ageing 1973;2:135-8.

23 Booker CL, Sacker A. Health over the life course: associations between age, employment status and well-being. In: McFall SL, Garrington C, eds. Early findings from the first wave of the UK's household longitudinal study. Colchester: Institute for Social and Economic Research, University of Essex, 2011:75-85.

24 Hank K, Erlinghagen M. Perceptions of job security in Europe's ageing workforce. Soc Indic Res 2011;103:427-42.

25 Office for National Statistics. Family spending: a report on the 2010 Living Costs and Food Survey. Newport: Office for National Statistics, 2011.

26 Joseph Rowntree Foundation. Pensioners' spending patterns and living standards: findings. York: Joseph Rowntree Foundation, 1995.

27 Anderson W, White V, Finney A. 'You just have to get by': coping with low incomes and cold homes. Bristol: Centre for Sustainable Energy, 2010.

28 Payette $\mathrm{H}$, Shatenstein $\mathrm{B}$. Determinants of healthy eating in community-dwelling elderly people. Can J Public Health 2005;96:S27-31.

29 Anderson A, Morris SE. Changing fortunes: changing food choices. Nutr Food SC 2000;30:12-15.

30 Shepherd R, Paisley CM, Sparks P, et al. Constraints on dietary choice: the role of income. Nutr Food Sci 1996;96:19-21.
31 Senauer B. Economics and nutrition. What is America eating? Proceedings of a symposium; Washington, DC: National Academy Press, 1986:46-57.

32 Dellava JE, Bulik CM, Popkin BM. Prices changes alone are not adequate to produce long-term dietary change. J Nutr 2010;140:1887-91.

33 Chouinard HH, Davis DE, LaFrance JT, et al. Fat taxes: big money for small change. Forum Health Econ Policy 2007;10:1-28.

34 Smed S, Jensen JD, Denver S. Socio-economic characteristics and the effect of taxation as a health policy instrument. Food Policy 2007;32:624-39.

35 Nordström J, Thunström L. Can targeted food taxes and subsidies improve the diet? Distributional effects among income groups. Food Policy 2010;36:259-71.

36 Schünemann HJ, Oxman AD, Vist GE, et al. Chapter 12: interpreting results and drawing conclusions. In: Higgins JPT, Green S, eds. Cochrane handbook for systematic reviews of interventions version 5.1. online: The Cochrane Collaboration (http://www.cochrane-handbook.org) 2008.

37 Deeks J, Dinnes J, D'Amico R, et al. Evaluating non-randomised intervention studies. Health Technol Assess 2003:7:1-192.

38 Davies L, Holdsworth D, Macfarlane D. Dietary fibre intakes in the United Kingdom before and after retirement from work. Hum Nutr Appl Nutr 1986;10:431-9.

39 Steen B, Nilsson K, Robertsson E, et al. Age retirement in women II. Dietary habits and body composition. Compr Gerontol 1988;2:78-82.

40 Lauque $S$, Nourashémi $F$, Soleilhavoup $C$, et al. A prospective study of changes on nutritional patterns 6 months before and 18 months after retirement. J Nutr Health Aging 1998;2:88-91.

41 Lundberg S, Startz R, Stillman S. The retirement-consumption puzzle: a marital bargaining approach. J Public Econ 2003:87:1199-218.

42 Nooyens AC, Visscher TL, Schuit AJ, et al. Effects of retirement on lifestyle in relation to changes in weight and waist circumference in Dutch men: a prospective study. Public Health Nutr 2005;8:1266-74.

43 Smith $\mathrm{S}$. The retirement-consumption puzzle and involuntary early retirement: evidence from the British Household Panel Survey. Econ J 2006;116:C130-C48.

44 Chung S, Popkin BM, Domino ME, et al. Effect of retirement on eating out and weight change: an analysis of gender differences. Obesity 2007; 15:1053-60.

45 Abusabha R, Namjoshi D, Klein A. Increasing access and affordability of produce improves perceived consumption of vegetables in low-income seniors. J Am Diet Assoc 2011:111:1549-55.

46 Helldán A, Lallukka T, Rahkonen 0 , et al. Changes in healthy food habits after transition to old age retirement. Eur J Public Health 2012;22:582-6.

47 Adams L, West S. Just above the breadline: living on a low income in later life. London: Age Concern England, 2006.

48 Brown NA, Smith KC, Kromm EE. Women's perceptions of the relationship between recent life events, transitions, and diet in midlife: findings from a Focus Group Study. Women Health 2012;52:234-51.

49 Graham H, Kelly M. Health inequalities: concepts, frameworks and policy. London: NHS Health Development Agency, 2004.

50 Bonnefoy J, Morgan A, Kelly M, et al. Constructing the evidence based on the social determinants of health: a guide. 2007, Report to the World Health Organization Commission on the Social Determinants of Health, from Measurement and Evidence Knowledge Network [online] http://www.who.int/social_determinants/ knowledge_networks/add_documents/mekn_final_guide_112007.pdf (accessed 10 Aug 2012)

51 Killoran A, Kelly M. Evidence based public health: effectiveness and efficiency. Oxford: Oxford University Press, 2010 